KS. JÓZEF SZYMAŃSKI* - WŁOCŁAWEK

\title{
OPIEKA DUSZPASTERSKA NAD POLAKAMI WE FRANCJI DO 1926 ROKU W OCENIE AMBASADORA ALFREDA CHLAPOWSKIEGO
}

Szybki napływ do Francji ludności polskiej pod koniec 1919 r. wymusił niemal natychmiast na polskich władzach państwowych i kościelnych konieczność szerokiej współpracy celem zapewnienia rodakom rozproszonym na terenie całego kraju rodzimej opieki duszpasterskiej ${ }^{1}$. Osiedlających się we Francji rodaków w ten sposób scharakteryzował wówczas ks. Paweł Kurtyka CM: „Prawie wszyscy robotnicy, którzy pracują we Francji, to tułacze za chlebem, niedostatek tylko zmusił ich do emigracji. Spotkałem jednak i jednostki, które zdaje się cel mają inny, jeden wyraźnie mi powiedział, że należy do tzw. defenzywy ${ }^{2}$, w kraju miał się bardzo dobrze, ale chce poznać tutejsze stosunki, inni, to działacze lewicowi, znajdą się i półinteligenci, którzy tam się udają, by objąć posady tłumaczy, kantyniarzy itd. Są i tacy, którzy w kraju porzucili i nie złe stanowiska jak agronoma, urzędnika Tow. ubezpieczeń, zwabieni wysoką walutą francuską. Takich którzyby tam mieszkali już przed wojną, jest bardzo mało, ale ogół składa się z familij zresztą bardzo dobrych, które tu przeniosły się z Westfalji oraz z rodzin napływających ustawicznie z Polski ze wszystkich jej prowincji. I tutaj trzeba wiele pracować nad złagodzeniem różnic dzielnicowych. Lud przybywający z Westafalji lub zaboru pruskiego, jest więcej rozgarnięty, więcej karny, pewny siebie, przyzwyczajony do większego dostatku, przyzwyczajony do stowarzyszeń, bez których i tutaj obyć się nie może. Ludność z zaboru rosyjskiego jest więcej bierna, poprzestaje na małem, trwożliwa, lubi pieniactwo i nie odczuwa potrzeby zrze-

${ }^{*}$ Ks. Józef Szymański - dr historii Kościoła.

${ }^{1}$ R. Dzwonkowski, Polska opieka religijna we Francji 1909-1939, Poznań-Warszawa 1988, s. 235-282; G. Garçon, Les catholiques polonais en France. Les années de fondation 1919-1949, Lille 2004, s. 45-73; Jeszcze o Misji Polskiej we Francji, „Roczniki Obydwóch Zgromadzeń Św. Wincentego a Paulo", Rok XXIX, 1 (1927) s. 198-209.

${ }^{2}$ Cytaty z zachowaniem oryginalnego stylu składni i ortografii. 
szania. Galicjanin idzie pośrodkiem”’3. W 1921 r. według oficjalnych danych przebywało we Francji 45 tysięcy obywateli polskich, zaś pięć lat później - 309 tysięcy $^{4}$. Z chwilą objęcia 13 maja 1922 r. kierownictwa Polskiej Misji Katolickiej (dalej: PMK) przez ks. Wilhelma Szymbora ${ }^{5}$ zaistniały warunki dla rozwinięcia

${ }^{3}$ Z pracy duszpasterskiej wśród robotników polskich we Francji, ,Roczniki Obydwóch Zgromadzeń Św. Wincentego a Paulo", Rok XXV, Nr 1(1923), s. 20-21

${ }^{4}$ J. Ponty, Les aumoniers polonais en milieu ouvrier immigre dans la France de l'entre deux guerres, w: Les contacts religieux franco-polonais du moyen age a nos jours. Relations, influences, images d'un pays vu par l'autre. Colloque international organisé par le C.N.R.S., GRECO nr 2. Histoire religieuse moderne et contemporaine et le Centre Interdiscipinaire d'Etudes des Religions de l'Université de Lille III. Lille 5-7 octobre 1981, Paris 1985, s. 568-575.

${ }^{5}$ Szymbor Wilhelm - kapłan Zgromadzenia Księży Misjonarzy św. Wincentego à Paulo (CM, lazarysta). Syn Antoniego i Teresy z d. Teller. Urodził się 16 października 1879 w Niwce k. Będzina. Do szkoły podstawowej uczęszczał w Mysłowicach. W 1893 zapisał się do Małego Seminarium Księży Misjonarzy na Kleparzu w Krakowie. Do zgromadzenia wstąpił w 1896, a 1 listopada 1898 złożył śluby zakonne. Studia filozoficzne i teologiczne odbył na Kleparzu i na Stradomiu. Święcenia kapłańskie przyjął 5 lipca 1903. Przez kolejnych pięć lat (1903-1908) mieszkał w domu kleparskim i pracował w grupie rekolekcyjno-misyjnej. W 1. 1908-1911 był dyrektorem Małego Seminarium w Krakowie na Nowej Wsi; następnie wrócił na Kleparz do pracy w grupie misyjnej, w której był dyrektorem. Do pracy rekolekcyjno-misyjnej włączył wówczas (1912-1914) regularne wyjazdy (późna jesień i wczesna wiosna) do skupisk robotniczych emigrantów polskich na terenie Niemiec, Danii i Szwecji. W okresie I wojny światowej prowadził działalność organizacyjno-charytatywną jako członek Książęco-Biskupiego Komitetu Pomocy w Krakowie. W 1. 1919-1921 powrócił do pracy rekolekcyjno-misyjnej i równocześnie redagował „Roczniki Obydwóch Zgromadzeń św. Wincentego à Paulo”. Na prośbę prymasa kard. Edmunda Dalbora z lipca 1921, 10 maja 1922 podjął się reorganizacji duszpasterstwa polonijnego we Francji. Zamieszkał w Paryżu, w domu generalnym Zgromadzenia i podjął urząd i obowiązki rektora Polskiej Misji Katolickiej we Francji. Prowadził ją do końca lipca 1928. Dokonał reorganizacji duszpasterstwa polonijnego, doprowadził do zjednoczenia rożnych organizacji religijnych w Związek Polskich Towarzystw Katolickich. Pod koniec lipca 1928 złożył rezygnację ze stanowiska rektora Misji. Pozostawił 30 placówek duszpasterstwa polskiego zorganizowanych w czterech dekanatach: paryskim, północnym, wschodnim i zachodnim. W duszpasterstwie polonijnym pracował do czerwca 1929. Na początku lipca tegoż roku, wraz z ks. Wiktorem Bieniaszem rozpoczął pracę rekolekcyjno-misyjną w ośrodkach duszpasterskich w Brazylii prowadzonych przez księży misjonarzy a także w innych parafiach - skupiskach polskich imigrantów. Od sierpnia 1931 pełnił obowiązki superiora domu oraz rektora Instytutu Teologicznego w Krakowie na Stradomiu. Wykładał teologię pastoralną i homiletykę, wygłaszał konferencje do chorych w Polskim Radio, a w 1. 1933-1938 był po raz drugi redaktorem „Roczników Obydwóch Zgromadzeń św. Wincentego a Paulo”. 1 października 1935 został rektorem Śląskiego Seminarium Duchownego w Krakowie oraz superiorem domu Zgromadzenia. We wrześniu 1939 po likwidacji seminarium przez władze okupacyjne, zamieszkał na Stradomiu, okazyjnie głosił rekolekcje parafialne oraz prowadził wykłady z teologii pastoralnej i homiletyki w konspiracyjnym seminarium księży salwatorianów w Krakowie na Zakrzówku. 11 sierpnia 1944 został aresztowany i więziony na Montelupich w Krakowie, a następnie w obozach koncentracyjnych: od 1 października 1944 we Flossenburgu, od 11 listopada w Mulsen, od 23 grudnia 1944 do 29 kwietnia 1945 w Dachau, nr obozowy 136986. Po wyzwoleniu z obozu, zamieszkał w domu generalnym misjonarzy w Paryżu i przez kilka miesięcy prowadził działalność duszpasterską w środowiskach polonijnych w rejonie Paryża. W 1946 powrócił do kraju i został superiorem domu oraz rektorem Instytutu Teologicznego na Stradomiu. Zmarł 9 grudnia 1946. Pochowany w grobowcu Zgromadzenia na cmentarzu 
bardziej planowanej współpracy PMK z Ambasadą Polską w Paryżu. Chodziło o to, by jak się wyraził rektor duszpasterze szli „ręka w rękę” z władzami polskimi. Na konieczność współpracy rządu, duszpasterzy, nauczycieli i przedstawicieli organizacji emigracyjnych 19 grudnia 1924 r. zwrócił również uwagę ambasador Alfred Chłapowski ${ }^{6}$, co w roku następnym skutkowało zawartym w tej sprawie porozumieniem? .

Ramy tej współpracy m.in. egzemplifikuje poniższy dokument, który jest odpowiedzią na wcześniejsze ustalenia kard. E. Dalbora z ambasadorem Chłapowskim.

Dokument oryginalny w formie maszynopisu, przechowywany jest w Archiwum Archidiecezjalnym w Gnieźnie, Archiwum Prymasa Polski, Akta Protektora Wychodźstwa Polskiego, Francja - PMK Varia, Dział III/15c, Ambasada Polska w Paryżu, Alfred Chłapowski Ambasador Rzeczypospolitej Polskiej, do prymasa Augusta Hlonda, Paryż dnia 17 marca 1927 r., k. 17.

$$
* * *
$$

Ambasada Polska W PARYŻu

4 załączniki [brak]
Paryż dnia 17 marca 1927 r.

Ściśle tajne i osobiste

Najprzewielebniejszy Księże Prymasie,

Różne ku temu złożyły się przyczyny, że dopiero teraz mam zaszczyt wypełnić tak dawno waszej Ekscelencji dane przyrzeczenie co do nadesłania informacji o działalności Polskiej Misji Katolickiej we Francji. W pierwszym rzędzie zawiniło moje zdrowie, które od końca zeszłego roku stale mi nie dopisuje i w znacznym stopniu hamuje załatwianie nawet bieżących spraw. Poza tym trudniej mi było, jak przypuszczałem, zebrać materiał beznaganny, który mimo moich zabiegów nie wypadł tak obficie, jak byłbym pragnął $\mathrm{w}$ interesie wszechstronnego wyświetlenia położenia rzeczy. Jestem atoli zmuszony ogra-

Rakowickim w Krakowie. Archiwum Polskiej Misji Katolickiej we Francji. H. Historia duszpasterstwa polskiego we Francji. VII. Życiorysy i jubileusze rektorów Kościoła polskiego, Kościoła w Paryżu i PMK we Francji, 1. Szymbor Wilhelm; Misjonarze św. Wincentego a Paulo w Polsce (1651-2001). II-1 Biografie, red. tomu II Jan Dukała CM, Kraków 2001, s. 484-490; Materiały do dziejów Polskiej Misji Katolickiej we Francji. Zeszyt 1. Księża polscy w duszpasterstwie okręgu paryskiego 1922-1929, O. B. Panek OC, Paris 1992, s. 111-113; S. Janaczek, Szymbor Wilhelm, w: Stownik Polskich Teologów Katolickich, t. 7, Warszawa 1983, s. 272-276; H. Olszar, Śp. ks. Wilhelm Szymbor, „Wiadomości Archidiecezjalne Katowickie” 1993 nr 6, s. 312-317 (literatura i źródła); J. Szymański, Duszpasterze Polonii i Polaków za granica. Słownik biograficzny, T. I, Lublin 2010, s. $142-144$.

${ }^{6}$ M. Wołos, Alfred Chłapowski (1874-1940). Biografia ambasadora Polski we Francji, Toruń 1999.

${ }^{7}$ Dzwonkowski, Polska opieka religijna we Francji 1909-1939, s. 235-282. 
niczyć się na razie do zużytkowania zebranych dotychczas materiałów także z tego względu, że za dwa dni wyjeżdżam na południe Francji, by zneutralizować skutki zimy wyjątkowo źle pod względem zdrowia przebytej.

Emigrację polską we Francji tworzą prawie wyłącznie robotnicy narodowości polskiej, przeważnie rzymscy-katolicy, w znacznej większości przywiązani do Kościoła Św. i spełniający obowiązki kościelne. Wpływy polityczne oraz środowiska w jakich pracują zrobiły jednak już poważny wyłom i nie małą ich część odsunęły i obecnie odsuwają od obowiązków religijnych. Fatalny ten objaw wywołuje jako skutek upadek moralności, zwiększające się stale zaniedbywanie rodzin, pozostawionych w Kraju, ogólna rozwiązłość obyczajów i - niestety - nawet bandytyzm w całem tego słowa znaczeniu.

Na poprawę tych stosunków, a przynajmniej na stabilizację obecnego stanu posiadania $\mathrm{w}$ tej dziedzinie może mieć decydujący wpływ racjonalnie prowadzona i kierowana praca duchowieństwa polskiego na emigracji.

Już krótko po objęciu mojego stanowiska w Paryżu - wiosną 1924 r. - przekonałem się, że organizacja ta należycie nie funkcjonuje choćby pod tym kątem widzenia, że zamiast jedności $\mathrm{w}$ duchowieństwie polskim i uczciwego podporządkowania się pod kierownictwo Rektora Polskiej Misji Katolickiej, w łonie tegoż duchowieństwa panowały różne koterie, wzajemnie się zwalczające. O stosunkach tych kilkakrotnie rozmawiałem z śp. Księdzem Kardynałem Dalborem. Wychodziłem przytem z tego założenia, że usuniecie największego szkodnika wśród duchowieństwa polskiego Ks. Prałata Helenowskiego ${ }^{8}$ będzie bardzo ważnym momentem ku uchyleniu najgorszych objawów.

${ }^{8}$ Helenowski (Gach) Wincenty - kapłan diecezji płockiej. Urodził się 8 marca 1893 w Helenowie k. Przasnysza. Syn Szczepana i Franciszki z d. Gnas. Do szkoły elementarnej z językiem rosyjskim uczęszczał w Helenowie. Naukę w gimnazjum rozpoczął w Mławie, następnie przeniósł się do Płocka, gdzie w Gimnazjum Św. Stanisława Kostki uzyskał świadectwo dojrzałości. Studia filozoficzno-teologiczne ukończył w Wyższym Seminarium Duchownym w Płocku. Tamże 30 maja 1918 z rąk bpa A. J. Nowowiejskiego przyjął święcenia kapłańskie. Posługę duszpasterską podjął jako wikariusz w Skrwilnie. W 1919 rozpoczął studia na Uniwersytecie Lubelskim z dziedziny polonistyki, po dwóch semestrach przeniósł się na uniwersytet w Poznaniu. Zamieszkał u sióstr wincentek w Górczynie, gdzie jednocześnie pełnił obowiązki kapelana. 21 grudnia 1921, decyzją Ministra Spraw Wewnętrznych, zmienił nazwisko z Gach na Helenowski. Konieczność przeprowadzenia kwerendy naukowej w Bibliotece Polskiej w Paryżu, wymuszona studiami w Poznaniu, umożliwiła mu podjęcie posługi duszpasterskiej wśród wychodźstwa polskiego we Francji. Początkowo pełnił ją w Paryżu, a następnie w Retonde (departament Osie). Od 1921 pracował na północy Francji, w Barlin (diec. Arras), od 1922 do 1926 w Bruay-en-Artois, Hersin-Coupigny, Paris, Rethondes. Od 1926 podjął posługę duszpasterską w parafii Świętej Trójcy w Montrealu (Kanada), gdzie jednocześnie kontynuował studia, uzyskując w grudniu 1929 dyplom doktora nauk społecznych, ekonomicznych i politycznych oraz dziennikarstwa. Po powrocie do Polski w 1931, został redaktorem dwutygodnika diecezjalnego „Hasło Katolickie”. W 1932 został proboszczem w Wyszynach k. Mławy. Stamtąd w 1934, w tym samym charakterze został przeniesiony do Czermna k. Gąbina, gdzie podjął się budowy świątyni. Ponadto, 18 listopada 1940 został administratorem parafii Gąbin z uprawnieniami wicedziekana dekanatu gąbińskiego. Od 10 lutego 1945 pełnił obowiązki proboszcza i dziekana w Gostyninie, zaś 1 sierpnia 1948 został proboszczem w Sochocinie, gdzie od lipca 1974 pozostawał rezydentem. 24 stycznia 1923 został szambelanem papieskim. Zmarł 23 września 1980 w szpitalu w Płocku. Pochowany został w Sochocinie. Materiały do dziejów Polskiej Misji Katolickiej we Francji, Z. IV/II: Księża polscy w duszpasterstwie Pótnocnej Francji 1922-1929, s. 8082; Materiały do dziejów Polskiej Misji Katolickiej we Francji. Zeszyt XVIII, s. 34; M. Grzybowski, Śp. Ks. prałat dr Wincenty Helenowski emerytowany proboszcz parafii Sochocin (1893-1980), 
Usunięcie to trwało nadzwyczaj długo, a w międzyczasie stosunki tylko się zaostrzyły, bo ks. Helenowski nie tylko wygrywał przeciwko ks. Rektorowi Szymborowi Ks. Biskupa Julien ${ }^{9}$ z Arras, którego potrafił omotać na tle finansowym, oraz wybitne francuskie osobistości, lecz namawiał nawet innych księży do wysłania niesłychanych paszkwilów do Ojca Świętego, do różnych Biskupów i Księży w Kraju w których rozsiewał fałszywe informacje dotyczące zarówno Księdza Rektora jak i urzędy polskie i członków Ambasady nie oszczędzając również i mnie.

W tym okresie trwającym aż do połowy ubiegłego roku niejednokrotnie docierały do mnie wiadomości, które utrwalały we mnie przeświadczenie, że nie tylko pod względem personalnym lecz i organizacyjnym Polska Misja Katolicka nie stoi na wysokości zadania. Mimo to nie interweniowałem na drodze urzędowej poza rozmowami z śp. Ks. Kardynałem Dalborem i Ks. Biskupem Łukomskim ${ }^{10}$, bo nie chciałem brać odpowiedzialności w materii, w której nie posiadam bezpośredniej kompetencji. Poza tem, obawiałem się, że interwencja moja $\mathrm{w}$ pierwszym rzędzie odbiłaby się na środowiskach pieniężnych stawianych do dyspozycji Ks. Rektora ze źródeł urzędowych. Wychodziłem z tego założenia, że Ks. Ks. Biskupi Polscy Francję odwiedzający lepiej ode mnie faktyczne położenie rzeczy osądzać i odpowiednio Komitet Ks. Ks. Biskupów poinformować mogą. Wobec powyższego zachowałem się na ogół biorąc biernie wobec Polskiej Misji Katolickiej we Francji.

Dopiero w lecie zeszłego roku zaszła okoliczność, która specjalnie mnie zaniepokoiła. Jeden z urzędników dobrze mi znany i zasługujący na zaufanie wyraził się w jednym ze swych raportów w sposób następujący: „Działalność na terenie wielu księży polskich, będących członkami źle zorganizowanej Polskiej Misji Katolickiej w Paryżu, którzy niejednokrotnie wyzyskują wychodźstwo i których działalność wymaga bacznej pieczy, a nawet zwrócenia odpowiedniej uwagi”.

Nie omieszkałem urzędnika tego zainterpelować z powodu tak ostrego sądu, lecz kilkakrotna wymiana zadań nie tylko z nim lecz i z innymi urzędnikami oraz pojedynczymi księżmi wykazała, że sąd ten jest w znacznym stopniu dostatecznie umotywowany.

Misja, względnie jej władze, zajmują się na wychodźstwie zbieraniem materiałów statystycznych, żalami robotników i sprawami ich organizacji, a nie znać i odczuwać się nie daje niezbędna łączność dość licznego stanu duchownego stałego specjalnie w północnej Francji. Działalność księży polskich nie jest uregulowana specjalnymi regulaminami Misji, nie jest dostatecznie kontrolowana, a znany jest wypadek, iż ksiądz nie mogący doczekać się odpowiedzi na liczne pisma do Misji samowolnie, jedynie w porozumieniu z francuskimi władzami duchownymi, objął stanowisko w jednym z przedsiębiorstw węglowych.

To załatwianie spraw swoich przez poszczególnych księży bezpośrednio z władzą

„Miesięcznik Pasterski Płocki” 10(1985), nr 3. s. 98-108; tenże, Duchowieństwo diecezji płockiej, T. 1, Cz. 1, s. 221-227; Dzwonkowski, Polska opieka religijna we Francji 1909-1939, s. 50, 126, 209, 263, 286; Leksykon Geograficzno-Historyczny Parafii i Kościołów Polskich w Kanadzie, red. E. Walewander, T. 1, Lublin 1992, s. 59, 61, 63; S. Wierzbicki, Byli naszymi duszpasterzami. Kaptani Kościoła Płockiego zmarli w latach 1901-2005, Płock 2005, s. 191; J. Szymański, Duszpasterze Polonii i Polaków za granica. Słownik biograficzny, T. II, Lublin 2011, s. 72-73.

${ }^{9}$ Eugène-Louis-Ernest Julien - Urodził się 16 stycznia 1856 w Canville les Deux (Seine Martime). Zmarł 14 marca 1930 w Arras. Święcenia kapłańskie przyjął 17 lipca 1881 w Rouen. Proboszcz parafii pw. Matki Bożej w Le Havre. Od 8 maja 1917 bp Arras. Doprowadził do odbudowy wielu świątyń w północnej Francji. Od 1925 członek Akademii Nauk Moralnych i Politycznych.

${ }^{10}$ T. Białous, Biskup Stanistaw Kostka Lukomski (1874-1948). Pasterz niezłomny, Rajgród 2010; W. Guzewicz, Duchowieństwo diecezji łomżyńskiej w II Rzeczypospolitej, Lublin 2003, s. 5862. 
duchowną francuską jest, jak twierdzą różni księża prawie regułą. Niewyjaśnioną się wydaje także sprawa nominacji i przeniesienia księży polskich i istotnie władze duchowne francuskie przerzucają ciężar odpowiedzialności za sprawy polskiej opieki duchownej na Misję, a ta ze swej strony tłumaczy swą bezradność stanowiskiem właśnie duchownych władz francuskich (odpisy charakterystycznej w tej sprawie korespondencji załączam).

Uregulowaną i wyjaśnioną być również winna sprawa stosunków materialnych, przydzielonych na czas pewien księży polskich do proboszczów francuskich. Został mi zacytowany wypadek w którym przydzielony ksiądz polski nie otrzymał żadnego wynagrodzenia, nie wiedział, czy proboszcz francuski zobowiązany jest dać mu całodzienne utrzymanie, czy też partycypować ma prawo w części dochodów parafii. Sytuacja jego, jak twierdził, była bardzo nie miła i krępująca.

Część księży, którzy tutaj sprawują, czy sprawowali swe obowiązki twierdziła, że Misja nie może zająć wobec duchowieństwa francuskiego należytego stanowiska, ponieważ rektor i jego najbliżsi współpracownicy należą do Zakonu Św. Wincentego a Paulo, mającego swą siedzibę generalną w Paryżu, 95 rue de Sčvres, wobec czego zbyt silne są w Misji wpływy francuskie, a ruchy ma skrępowane wiążącymi dyspozycjami francuskiego zakonu.

Jako cechę złej organizacji Misji podnieść również należy brak planu w obsadzaniu przez księży polskich wolnych jeszcze dzisiaj placówek duszpasterskich, które w przyszłości niewątpliwie obejmą księża francuscy, względnie młodsi księża spośród wychodźstwa, którzy za wiadomością, niestety Misji kształcą się w seminariach francuskich, zatracając całkowicie swą polskość. Rażącym tego przykładem jest seminarium w Bethune (notatka w załączniku).

Podkreślić także wypada ten niezdecydowany stosunek Misji do zjawisk, wobec których, celem uniknięcia niepożądanych komplikacji, zająć należy wyraźny, określony stosunek: - w lecie ub. r. dzięki wahaniom Misji zatrzymała się na dłużej we Francji bliżej nieznana, jakoby siostra - Teresa Bielawska, która nie będąc popierana przez Misję uzyskała zaświadczenie i list polecający Ks. Rektora do jednego z księży na północy, który zresztą nie był powołany do opiekowania się polecaną i nie mógł w ogóle, ze względu na swe niewyjaśnione stanowisko wobec władz duchownych francuskich, przedsiębrać jakichkolwiek kroków, celem udzielenia pomocy w zainstalowaniu się siostry (?) Teresy na północy. Słyszałem o dużych trudnościach, z jakimi miała Misja do czynienia, by skłonić siostrę Teresę do opuszczenia granic Francji (odpis pisma Konsulatu w Lille z dnia 31.VII. 1926, Nr 16337/Pf/464/26 w załączeniu). Jak dzisiaj ta sprawa wygląda nie umiem powiedzieć, bo ją z oczu straciłem, a nie zdołam już przed wyjazdem moim stwierdzić istotnego stanu rzeczy, lecz wiem, że owa pseudo siostra wyzyskiwała pod płaszczykiem żłobków samowolnie zakładanych robotników polskich w Paryżu i że pani Ambasadorowa tej działalności szkodliwej stanowczo przeciwstawić się musiała. Z powodu tych zajść ostrzegłem osobiście Ks. rektora Szymbora bardzo poważnie, zarzucając mu lekkomyślne poparcie podejrzanej osoby i grożąc, że się postaram o jej wydalenie.

Chciałbym tutaj nadmienić, że i z kół urzędniczych i duchownych często wobec mnie zaznaczano, iż polska zwierzchnia władza duchowna we Francji cieszyć się powinna bezwzględnym szacunkiem i głębokim poważaniem duchowieństwa polskiego, że musi je nie tylko należycie zorganizować i prowadzić silną ręką po wyraźnie wytkniętej linii prac, wiążących nierozerwalnie kierunek religijny z kierunkiem państwowo-narodowym, chroniąc wychodźstwo przed wyzyskiem słabych często charakterów. Długoletnie rozbicie na dwa obozy duchowieństwa polskiego w północnej Francji i taki stan umysłów, który dopuścił do oświadczenia jednego z obecnie jeszcze działających tutaj księży, na zjeździe polskiego duchowieństwa, w lecie 1924 r., wobec Ks. Biskupa Łukomskiego i Ks. Szym- 
bora, iż „Rektor Misji jest zdrajcą sprawy katolickiej i narodowej” - nie sprzyja scalaniu tutejszego duchowieństwa polskiego, wzajemnemu zaufaniu i tak niezbędnemu wzrostowi powagi jego zwierzchnika, tym więcej, że oświadczenie pokryte zostało podobno głuchym milczeniem.

Przechodząc do drugiej części zebranych przeze mnie informacji, pozwalam sobie podać kolejno Waszej Ekscelencji różne fakty charakteryzujące działalność poszczególnych księży i uzasadnić konieczność ściślejszej kontroli nad ich czynnościami i określenia zakresu ich prac, że tak nazwę biurowych.

Polem do nadużyć, najczęściej nieuchwytnych, jakich dopuszczają się księża na emigracji, jest ich działalność w dziedzinie ułatwiania wychodźstwu wyrabiania wszelkich niezbędnych mu dokumentów urzędowych w różnych okolicznościach życia. Za czynności tego rodzaju księża naznaczają nieraz wygórowane opłaty i mają podobno z tego tytułu dość znaczne z tego dochody. W związku z tymi sprawami pośredniczą często w Konsulatach, niektórzy prowadzą po prostu biura tłumaczeń i porad i starają się przyciągnąć klientów przez odpowiednią reklamę.

Za zupełnie już niedopuszczalne dla duchowieństwa na emigracji uważam prowadzenie wszelkich interesów na zysk obliczonych, co niestety do niedawna miało miejsce i co tylko z trudem zostało na północy Francji zlikwidowanem.

Na wychodźstwie działać powinien ksiądz społecznik, materialnie odpowiednio uposażony a zabronionem być winno prowadzenie wszelkich interesów i przedsiębiorstw na zysk obliczonych, pomoc zaś wychodźstwu przy załatwianiu spraw z urzędami krajowymi, czy Konsulatami i rady wszelkie udzielane być winny przez duchowieństwo polskie polskim emigrantom bezpłatnie. Przykładem duchownego, jakich na emigracji tolerować nie wolno, był na tutejszym terenie ks. prałat Helenowski, który pozostawiwszy smutną pamięć i zlikwidowawszy z trudem swoje przedsiębiorstwa opuścił Bruay-les-Mines dopiero w październiku r. ub. Ks. Helenowski (Wincenty Gach) był właścicielem czterech księgarni, dwóch klinik, (na zewnątrz jako właściciel figurował p. Porayski), prowadził kantory wymian, był inicjatorem założenia Centralnego Banku Związkowego w Lille, który obecnie jest już w likwidacji z wielką stratą dla rzesz robotniczych, wreszcie prowadził dobrze zorganizowane biuro na plebanii, w którym załatwiał najróżnorodniejsze sprawy począwszy od sprowadzania dokumentów z kraju dla robotników, przekazywania ich oszczędności, a skończywszy nawet na udzielaniu Żydom pod zastaw pożyczek, wreszcie działalność jego biura nosiła charakter wywiadowczo-informacyjny. Poprzez przekupywanie działaczy wychodźczych wprowadzał tutaj korupcję, której objawy po jego wyjeździe stopniowo ustępują.

Najważniejszym ośrodkiem emigracji polskiej we Francji jest okręg konsularny w Lille, o którym kilka notatek podać pragnę. Obecnie w jego okręgu pracuje księży stałych 15 (piętnastu), uwzględniając w tej liczbie dwóch wikariuszy stwierdzić należy, że stałych placówek duszpasterskich 230.000 rzesza emigracji polskiej posiada 13, prócz tego pełnią funkcję duszpasterzy dojeżdżający raz na tydzień księża studenci dwaj z Paryża, jeden z Lille.

Z pośród tych 13 placówek duszpasterskich, 7 (siedem) zajmuje się sporządzaniem dokumentów dla wychodźstwa za opłatą, żądając często za te czynności wygórowanych opłat, a czasem wchodząc nawet w porozumienie z thumaczami oficjalnymi przy Trybunałach, celem uniknięcia ich konkurencji i z obawy przed obniżeniem osiąganego z tego źródła dochodu.

Dziekanem na okręg Konsulatu R.P. w Lille mianowany został przez ks. rektora 
Szymbora ks. Masny-Mkniewski ${ }^{11}$ z Oignies. Żywa działalność ks. Masnego ma wiele cech dodatnich i gdyby władza duchowna swym wpływem starała się usunąć ujemne stanowiłby on cenną siłę w pracach czynników polskich na terenie emigracyjnym.

Poza działalnością ściśle duchowną ks. dziekan Masny Mkniewski występuje również jako działacz społeczny. Niestety nie dość taktowana akcja ks. dziekana powoduje zatargi z miejscową kolonią robotniczą. Zatargi, (jak np. w ub. r. szkolnym) tego rodzaju, bywały wywołane przez ks. dziekana jego - jak mi donoszono - niewłaściwymi enuncjacjami.

Ks. Masny prowadzi przy plebanii coś w rodzaju biura próśb i tłumaczeń.

Na skutek tego, że ks. Masny pobierał wygórowane opłaty za tłumaczenie dokumentów (dwa razy tyle co tłumacz przysięgły), oraz oddziaływał na merostwa aby tylko jego tłumaczenia honorowano - mimo, że praw tłumacza przysięgłego nie posiadał, a tłumaczenia swoje legalizował w Konsulacie - konsulat wezwał ks. dziekana do złożenia wyjaśnień.

Dopiero po interwencjach Konsulatu tak u samego ks. Masnego, jak w Prefekturze, ks. Masny zaprzestał oficjalnie zajmować się tłumaczeniami - wchodząc w ścisły kontakt z tłumaczem przysięgłym p. Dyjasem, ograniczając się obecnie do pewnego procentu za pośrednictwo w dostarczaniu mu dokumentów.

Tego rodzaju postępowanie oddziaływa ujemnie na skądinąd dodatnie zadania i rolę ks. dziekana Masnego, a uprawianie procederu płatnego pośrednictwa w sprawach tłumaczeń aktów prawnych itd. często wzbudza rozżalenie u poszczególnych emigrantów - moim zdaniem całkiem słuszne.

Ks. Sadowski ${ }^{12}$ z Valenciennes, wychowany we Francji, władający lepiej językiem

${ }^{11}$ Masny-Mkniewski Andrzej - kapłan Zgromadzenia Księży Misjonarzy św. Wincentego a Paulo CM (lazarysta). Urodził się 22 lipca 1877 w Łące. Syn Andrzeja i Zuzanny z d. Jucha. Naukę na poziomie średnim odbywał od 1891 w Małym Seminarium w Krakowie. W 1895 wstąpił do Zgromadzenia Księży Misjonarzy i rozpoczął nowicjat. Święcenia kapłańskie przyjął 6 lipca 1902. Pracował jako wikariusz w parafii Jezierzany w archidiecezji lwowskiej. Od 1904 pracował jako katecheta w Tarnowie. W 1905 został przeniesiony do Krakowa na Kleparz, gdzie pełnił obowiązki kapelana w zakładzie Helclów. Od 1907 pracował ponownie w archidiecezji lwowskiej najpierw w Sarnkach Dolnych, następnie w Witkowie Nowym (1908-1911). Od 1911-1914 mieszkał w Krakowie na Kleparzu. W 1914 został wikariuszem w Jezierzanach, pozostał tam jednak tylko rok, pełniąc następnie posługę kapelana w domach sióstr miłosierdzia. Pod koniec I wojny światowej został powołany do wojska pruskiego. Od 1918 rozpoczął posługę kapelana w Wojsku Polskim i pełnił ją do końca 1920. Po zakończeniu pracy w wojsku przez dwa lata był wikariuszem w Olczy k. Zakopanego. Od 1922 do 1927 pracował w duszpasterstwie polonijnym w Oignies (dep. Pas-de-Calais), dojeżdżając do kilku kolonii polskich; Carvin, Garguebel, Leforest, Libercourt, Montcheau, Oignies, Ostricourt, Thumeries, Wahagnies. Po powrocie do Polski pomagał w duszpasterstwie przy kościele rektoralnym w Krakowie na Kleparzu. Od 1931 pracował w parafii św. Rodziny w Tarnowie w charakterze wikariusza i katechety. Ostatnie lata życia był rezydentem w tej parafii. Zmarł 5 marca 1949 w Tarnowie. Pochowany został na starym cmentarzu miejskim w grobowcu księży misjonarzy. Materiaty, z. IV/II, Księża polscy w duszpasterstwie Pótnocnej Francji 1922-1929, s. 107-110; S. Janaczek, Masny Andrzej, w: Stownik Polskich Teologów Katolickich, T. 6, Warszawa 1983, s. 428-430.

${ }^{12}$ Sadowski Jan - kapłan diecezji płockiej; od 2 stycznia 1922 diecezji Cambrai. Urodził się 24 czerwca 1889 w Cywinach na Ukrainie. We Francji przebywał od września 1908. Gimnazjum ukończył w Poitiers, a studia teologiczne w Paryżu. Święcenia kapłańskie przyjął 29 lipca 1921. Inkardynowany do diec. Cambrai. Od 2 stycznia 1922 pełnił posługę duszpasterską wśród rodaków w: Valenciennes (Nord), od 30 grudnia 1940 w Bourg d'Oisans (Isere), skąd 30 grudnia 1944 powrócił 
francuskim niż polskim, prowadzi jedno z większych biur porad dla wychodźstwa. $\mathrm{Na}$ dokumentach tłumaczonych na język francuski ks. Sadowski umieszczał adnotację, iż jest „Traducteur agréé officiellement”. Trybunał jednak w Valenciennes zawiadomił Konsulat, że ks. Sadowski stałym tłumaczem nie jest, ale sąd powierzał mu często dokonywanie tłumaczeń dokumentów polskich. Biuro swoje ks. Sadowski reklamował w sposób, jaki obrazuje załączona oryginalna ulotka. Ulotkę taką otrzymał od Konsulatu ks. dziekan

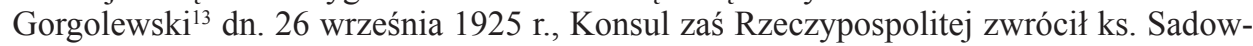
skiemu uwagę, na niedopuszczalność tego rodzaju niesmacznej reklamy. Dokumentów stwierdzających pobieranie wygórowanych opłat za czynności „biurowe” przez ks. Sadowskigo nie udało mi się uzyskać, wiem atoli że do Konsulatu dochodziły jednak skargi w tym kierunku.

Ks. Majkowski ${ }^{14}$ z Sallaumines, który zgodnie z opinią organizacji robotniczych wy-

do Valenciennes. Dojeżdżał do (16) polskich kolonii. W rejonie Valenciennes zamieszkiwało 28.000 Polaków. Systematycznie uczestniczył w zebraniach PMK. Zmarł 29 grudnia 1950 w Valenciennes. Archiwum Polskiej Misji Katolickiej we Francji. P. Personalia. VI. Ankieta personalna kapłanów MPK we Francji 1945(-1950); Materiaty do dziejów Polskiej Misji Katolickiej we Francji. Zeszyt I. Księża polscy w duszpasterstwie okręgu paryskiego 1922-1929, O. B. Panek OC, Paris 1992, s. 101; Materiaty do dziejów Polskiej Misji Katolickiej we Francji. Zeszyt IV II/II, s. 118-119; Materiaty do dziejów Polskiej Misji Katolickiej we Francji. Zeszyt XVIII, s. 82; J. Szymański, „Nie chcemy tego ukrywać” - oczami świadków. Sytuacja duszpasterstwa polonijnego w Pólnocnej Francji w 1928 r., „Archiwa Biblioteki i Muzea Kościelne”, 98 (2012) s. 413.

${ }^{13}$ Gorgolewski Józef - kapłan archidiecezji poznańskiej. Urodził się 6 marca 1889 w Smerzynie k. Żnina. Święcenia kapłańskie przyjął 11 lutego 1912. Od 1 marca pełnił obowiązki wikariusza w parafii Św. Floriana na Jeżycach, a od 1 stycznia 1915 był wikariuszem w parafii Matki Boskiej Bolesnej w Poznaniu. 1 stycznia 1917 został wikariuszem w Grodzisku. W 1. 1919-1924 pełnił obowiązki kapelana wojskowego. W 1925 pełnił posługę duszpasterską wśród wychodźstwa polskiego we Francji. Był duszpasterzem w: Douai, Lens, Montceau-Les-Mines, Notre-Dame-De-Lumieres, Villers, Waziers. Po powrocie do kraju, 1 maja 1928 podjął obowiązki administratora i proboszcza parafii Matki Boskiej Bolesnej. 20 kwietnia 1940 został aresztowany przez Niemców. Od 24 maja 1940 był więźniem obozu koncentracyjnego w Dachau, a od 2 sierpnia Mauthausen Gusen, gdzie pracował w kamieniołomach. Od 2 grudnia 1940 powtórnie w Dachau. 23 października 1942 został wywieziony w tzw. ,transporcie inwalidów” do Hartheim i zamordowany w komorze gazowej.

${ }^{14}$ Majkowski Hilary - kapłan diecezji łomżyńskiej, od 1 lipca 1934 kapłan archidiecezji warszawskiej. Urodził się 20 czerwca 1895 w Chodkowie-Rogowie k. Przasnysza. Syn Aleksandra i Pauliny z d. Chodkowska. Ukończył gimnazjum w Łomży. Święcenia kapłańskie otrzymał 20 stycznia 1919. Uczestniczył w wojnie polsko-bolszewickiej. Był wikariuszem w Augustowie (1920) i Wiźnie (1921). Od września 1923 został prefektem w Kolnie. W lipcu 1924 został proboszczem w Kapicach. Rok później był proboszczem w Kuziach. Od 9 marca 1925 był duszpasterzem wśród Polaków w Barlin, we Francji. W grudniu 1925 został przeniesiony do Sallaumines, gdzie pracował do 31 stycznia 1928. Od 1 lutego 1928 do 15 września 1930 pracował w Metzu, chociaż już 17 kwietnia 1930 został rektorem Polskiej Misji Katolickiej w Luksemburgu. Pracował tam do 1 czerwca 1931 i wyjechał z Księstwa. Podjął obowiązki duszpasterza Polaków w Souvret (Belgia). Do Polski wrócił w 1933. Początkowo był substytutem w Kapicach i po kilku miesiącach proboszczem w parafii Chlebiotki. 1 czerwca 1934 inkardynował się do archidiecezji warszawskiej. Obją wikariat w parafii św. Stanisława Kostki w Warszawie. W lutym 1936 został administratorem parafii Miłonice. Tam został aresztowany 6 października 1941, a 30 października osadzony w obozie koncentracyjnym w Dachau, nr obozowy 28202. Na zagazowanie został wywieziony 18 maja 1942. Archiwum Diecezjalne w Łomży, Akta osobowe ks. Majkowski Hilary (1895-[1942]); Archiwum 
zyskuje wychodźstwo, pobrał swego czasu od nijakiego Perona Leona fr. 50 - za wypełnienie dwóch kwestionariuszy paszportowych, żądając jakoby za tę czynność fr. 75 - (zeznania w tej sprawie znajdują się w aktach Konsulatu w Lille i zakomunikowane były swego czasu ks. dziekanowi Gorgolewskiemu).

Co do osoby ks. Śledziowskiego ${ }^{15}$ z Marles-les-Mines, to Konsulat posiada w aktach skargę, iż robi on nowożeńcom trudności o ile metryk niezbędnych do zawarcia małżeństwa nie tłumaczą u niego.

Ks. Crueize z Dourges, Francuz mówiący po polsku zajmuje się pośredniczeniem w umieszczaniu robotników z północy w gospodarstwach rolnych na południu Francji. Nadużycia z jego strony nie są znane, jednak jest charakterystycznym oświadczenie jednego zainteresowanego robotnika w liście do Związku Robotników Polskich w Lille, iż „ksiądz powinien kościoła patrzeć nie handlować ludźmi jak Żyd końmi” - dla powagi stanu duchownego jest to nader niepożądanym. Ks. Crueize wzywany był - o ile wiem - w tej sprawie do Konsulatu.

Ks. Bross ${ }^{16}$, który opuścił już Pacquencourt pobrał w marcu ub. r. fr. 80 - za sporządzenie dwóch tłumaczeń świadectw niezbędnych do zawarcia małżeństwa, zaś za zała-

Polskiej Misji Katolickiej we Francji. P. Personalia. V, 44, Majkowski Hilary; Archiwum Akt Nowych, Ministerstwo Wyznań Religijnych i Oświecenia Publicznego, Dep. V Wyznań Religijnych, Akta osobowe księży, sygn. 493, k. 222; Materiały do dziejów Polskiej Misji Katolickiej we Francji. Zeszyt III, s. 72-73; B. Kołodziej, Opieka duszpasterska nad Polakami za granica 1919-1938, Poznań 2003, s. 90; Szymański, Duszpasterze Polonii i Polaków za granica, T. 1, s. 95-96.

${ }^{15}$ Śledziowski Ignacy - kapłan archidiecezji lwowskiej. Urodził się 25 lipca 1866 w Chrościu (Staniątki). Święcenia kapłańskie przyjął 7 czerwca 1896. Posługę duszpasterską wśród wychodźstwa polskiego we Francji pełnił od 23 lutego 1921 w: Amiens, Argenteuil, Bonne-Fontaine par Rouge, Calonne-Ricouart, Coueron, Evaux-Les-Bains, Marles-Les-Mines, Montmorillonn, NoeuxLes-Mines, Senots (Blequencourt-Senots). Zmarł 18 lutego 1951. Archiwum Polskiej Misji Katolickiej we Francji. P. Personalia. P. IV. Ankieta personalna księży pracujących w ośrodkach duszpasterskich PMK w 1943.

${ }^{16}$ Bross Stanisław - kapłan archidiecezji poznańskiej. Urodził się 17 października 1895 w Witkowie k. Gniezna. Uczęszczał do gimnazjum w Trzemesznie i Gnieźnie, gdzie w 1914 uzyskał świadectwo dojrzałości. Studia teologiczne rozpoczął na uniwersytecie we Wrocławiu, a kontynuował w Münster, gdzie studiował jednocześnie filozofię (1915-1918). Po odbyciu rocznego studium teologiczno-pastoralnego w Gnieźnie, 5 kwietnia 1919 przyjął święcenia kapłańskie. Od 1 sierpnia pracował jako wikariusz w Żninie. W 1924 wyjechał na dalsze studia do Paryża, gdzie w 1928 uzyskał doktorat z teologii i prawa kanonicznego. Tam jednocześnie pełnił posługę duszpasterską wśród wychodźstwa polskiego w: Cambrai, Lens, Montigny en Ostrevent, Paris, Pecquencourt, Waziers. Po studiach odbył podróż naukową po Europie. Po powrocie do kraju, został dyrektorem Naczelnym Instytutu Akcji Katolickiej z siedzibą w Poznaniu (do 1938). Był też założycielem i redaktorem tygodnika „Kultura” (1936-1938). Dla instytutów Akcji Katolickiej założył w 1931 miesięcznik „Ruch Katolicki”. Był: moderatorem Sodalicji Mariańskiej Pań w Poznaniu; delegatem Episkopatu Polski dla Związku Kobiet w Polsce; organizatorem katolickich zjazdów i spotkań; członkiem rady Społecznej przy Prymasie Polski. Po ustąpieniu w 1939 z zajmowanych funkcji, wyjechał do Rzymu. Przed wybuchem II wojny światowej powrócił do kraju. 9 listopada 1939 został aresztowany przez Niemców i osadzony w więzieniu w Poznaniu, następnie w Kazimierzu Biskupim. Od 24 maja 1942 przebywał w obozie koncentracyjnym w Dachau. Po powrocie do kraju w 1947 pracował w kurii prymasowskiej. W 1953 został wikariuszem generalnym archidiecezji gnieźnieńskiej. W 1956 przeszedł na emeryturę i zamieszkał we Wrocławiu. Tam zmarł 28 stycznia 1982. F. Galewicz, Bross Stanisław (1895-1982), w: Stownik Biograficzny Katolicyzmu Społecznego w Polsce, 
twienie wszelkich formalności związanych ze ślubem fr. 160. Odnośny protokół przesłał Konsulatowi Związek Robotników Polskich w Lille.

Urzędy nie zajmowały się dotychczas zbadaniem szczegółowym działalności księży, którym opinia wychodźcza zarzuca wyzysk emigranta. Badania takie stanowią zadanie nadzwyczaj delikatne, które by należało koniecznie - jako zbędne - móc uchylić.

Nim przejdę do zreasumowania powyższych - urywkowo przedstawionych - stwierdzeń pochodzących z różnych źródeł, pragnąłbym zaznaczyć że nie jest moim zamiarem generalizowanie ich. Jest cały szereg duchownych polskich we Francji, którzy są kapłanami bez zarzutu i stoją najzupełniej na wysokości trudnego zadania. By nie były tylko cienie, lecz i światła, pozwalam sobie zacytować Waszej Ekscelencji ustęp z pisma z prowincji (z północy), które mam przed sobą: „Na szczęście wszyscy księża pracujący tutaj są patriotami, połowa spośród nich pracuje społecznie, a niech mi będzie wolno wymienić trzy nazwiska ks. ks. Garsteckiego ${ }^{17}$ (Lens),

T. 1, Lublin 1994, s. 56-57; Materiaty do dziejów Polskiej Misji Katolickiej we Francji. Zeszyt I. Księża polscy $w$ duszpasterstwie okręgu paryskiego 1922-1929, s. 11-12.

${ }_{17}$ Garstecki Czesław - kapłan archidiecezji poznańskiej. Urodził się 14 czerwca 1896 w Poznaniu. Syn Marcina i Stanisławy z d. Maniewska. Uczęszczał do gimnazjum św. Marii Magdaleny. Po uzyskaniu świadectwa dojrzałości, 1 lipca 1921 wstąpił do Wyższego Seminarium Duchownego w Poznaniu. 26 maja 1926 w Gnieźnie, przyjął święcenia kapłańskie z rąk kard. E. Dalbora. Pracował jako wikariusz w parafii św. Mikołaja w Inowrocławiu. Posługę duszpasterską wśród wychodźstwa polskiego we Francji rozpoczął 20 marca 1926 w Lens, jako dyrektor stowarzyszeń i bractw kościelnych we Francji, a od 1 marca 1933 w Sallaumines także jako duszpasterz wśród polskich górników kopalni Bethune, zamieszkujących w Auchy, Mazingarbe, Brebis. Po powrocie do kraju, 15 grudnia 1935 został proboszczem w Baszkowie. 1 stycznia 1937 objął parafię św. Stanisława Kostki w Poznaniu. Podczas okupacji posługę duszpasterską pełnił na terenie Nałęczowa. Po zakończeniu działań wojennych na nowo podjął posługę w tej samej parafii. Zmarł po nabożeństwie na schodach kościoła 20 maja 1953 r. Pochowany na cmentarzu parafialnym. Archiwum Polskiej Misji Katolickiej we Francji. J. Misje - ośrodki duszpasterskie. II. Dekanat Pas de Caleais. 8. Lens. 8. 1. Korespondencja 1929-1947; 15. Salaumines 1929-1986. 1. Korespondencja 1929-1939; P. Personalia. I. P. I. „Akta osobowe księży”, do 1939, 14. Garstecki Czesław; P. V. Akta osobisto duszpasterskie księży pracujących w ośrodkach duszpasterskich PMK we Francji, gromadzone po 1945, 65. Garstecki Czesław; Materiały do dziejów Polskiej Misji Katolickiej we Francji. Zeszyt IV II/II. Księża polscy w duszpasterstwie Pólnocnej Francji 1922-1929, s. 83-86; Materiały do dziejów Polskiej Misji Katolickiej we Francji. Zeszyt XVIII. Duchowieństwo polskie we Francji od 1922 r. Prezentacja stanu badań - katalog, O. B. Panek OC, Paris 1996, s. 34; „Miesięcznik Kościelny Archidiecezji Poznańskiej", 8 (1957) s. 291-292; M. Banaszak, Garstecki Czesław (1896-1953), w: Stownik Polskich Teologów Katolickich 1918-1981, red. L. Grzebień SJ, T. 6, Warszawa 1983, s. 426-427. 
Kaczmarka ${ }^{18}$ (Bruay) i Marciniaka ${ }^{19}$ (Lille) zetknięcie się z którymi pozostawia mi uczu-

${ }^{18}$ Kaczmarek Czesław - kapłan diecezji płockiej, od 24 maja 1938 biskup ordynariusz diecezji kieleckiej. Urodził się 16 kwietnia 1895 w Lisewie Małym k. Sierpca. Syn Józefa i Franciszki Bronisławy z d. Rogozińska. Po ukończeniu szkoły wiejskiej wstąpił do seminarium nauczycielskiego w Wymyślinie (od 1997 część Skępego), gdzie w 1916 otrzymał dyplom ukończenia seminarium nauczycielskiego, udzielał prywatnych korepetycji. W 1917 wstąpił do Wyższego Seminarium Duchownego w Płocku. Przed przyjęciem święceń kapłańskich brał udział w walce przeciwko Rosji sowieckiej. Święcenia kapłańskie z rąk bpa A. Nowowiejskiego przyjął 20 sierpnia 1922 w kościele parafialnym w Nasielsku. Od listopada podjął studia w zakresie socjologii na uniwersytecie w Lille, gdzie w 1927 uzyskał doktorat w Instytucie Nauk Społecznych i Politycznych. Podczas studiów prowadził też aktywną pracę duszpasterską wśród polskiej emigracji. Dojeżdżał do kolonii Polaków m.in. do Bruay-sur-l'Escaut, Waziers i Auby. Po powrocie do Polski w 1928, objął urząd sekretarza Związku Młodzieży Polskiej Męskiej, a następnie został dyrektorem płockiego Diecezjalnego Instytutu Akcji Katolickiej. Był inicjatorem założenia w 1936 w Płocku Wieczorowego Uniwersytetu Wykształcenia Religijnego, który w 1938 przekształcono w Instytut Wyższej Kultury Religijnej. 24 maja 1938 został biskupem diecezjalnym diecezji kieleckiej. 20 stycznia 1951 został aresztowany pod zarzutami szpiegostwa na rzecz Stanów Zjednoczonych oraz Watykanu, faszyzacji życia społecznego, nielegalnego handlu walutami oraz kolaboracji. Był torturowany w areszcie śledczym. W trakcie procesu pokazowego (od 14 do 22 września 1953) przyznał się do zarzucanych mu czynów. Za prowadzanie antypaństwowego i antyludowego ośrodka oraz ,za kolaborację z Niemcami, usiłowanie obalenia ustroju PRL i propagandę na rzecz waszyngtońsko-watykańskich mocodawców”. został osądzony i skazany na 12 lat więzienia. Na mocy postanowienia Naczelnej Prokuratury Wojskowej 8 lutego 1955 ze względów zdrowotnych zawieszono wykonanie wyroku. 3 lutego 1956 został ponownie aresztowany i osadzony w mokotowskim więzieniu. 7 maja 1956 Wojskowy Sąd Garnizonowy zastosował amnestię, jednakże 17 maja doręczono mu wiadomość o przymusowym skierowaniu go na czas nieograniczony do klasztoru w Rywałdzie Królewskim. Zmożony chorobą oraz złymi warunkami ordynariusz podjął samodzielną decyzję o wyjeździe do Warszawy 22 września 1956, gdzie przebywał do 30 marca 1957, kiedy Naczelna Prokuratora Wojskowa wydała postanowienie o umorzeniu śledztwa w sprawie bpa Kaczmarka i współoskarżonych z nim osób z powodu braku dostatecznych dowodów. 2 kwietnia 1957 wrócił do Kielc. W 1958 przeprowadził synod diecezjalny, dokonał reorganizacji administracyjnej diecezji. 9 czerwca 1959 rząd PRL zażądał od episkopatu Polski jego usunięcia z zajmowanego stanowiska. Zmarł 26 sierpnia $1963 \mathrm{w}$ Lublinie. W 1990 został pośmiertnie uniewinniony i zrehabilitowany. 7 listopada 2007 ,za wybitne zasługi dla niepodległości Rzeczypospolitej Polskiej, za działalność duszpasterską i charytatywną" został pośmiertnie odznaczony Krzyżem Wielkim Orderu Odrodzenia Polski. Cz. Kaczmarek, L'Emigration polonaise en France aprčs la guerre, Paris 1928; „Miesięcznik Pasterski Płocki” 18 (1923) nr 9-10, s. 161; Z uroczystości ingresowych i konsekracyjnych J. E. Ks. Biskupa Czesława Kaczmarka, „Kielecki Przegląd Diecezjalny”, 1938 nr 9, s. 278-279; M. Grzybowski, Kaczmarek Czesław, biskup kielecki, w: Stownik Polskich Teologów Katolickich, T. 6, Warszawa 1983, s. 12-14; Materiaty, z. I, Księża polscy w duszpasterstwie okręgu paryskiego, s. 41-42; K. Krasowski, Biskupi katoliccy II Rzeczypospolitej, Słownik biograficzny, Poznań 1996, s. 109-111; J. Śledzianowski, Kaczmarek Czesław, bp, w: Encyklopedia Katolicka ,t. 8, kol. 307-309 (bibliogr.).

${ }^{19}$ Marciniak Ignacy - kapłan diecezji płockiej. Urodził się 25 lipca 1897 we wsi Piotrkówek. Do szkoły powszechnej uczęszczał w Słubicach, a do średniej w Gostyninie. W 1915 wstąpił do Wyższego Seminarium Duchownego w Płocku. Święcenia kapłańskie z rąk bpa A. Nowowiejskiego przyjął 20 sierpnia 1922 w kościele parafialnym w Nasielsku. W listopadzie 1922 wyjechał do Francji na studia z nauk przyrodniczych na uniwersytecie w Lille. W Lille w domu Sióstr Miłosierdzia pełnił funkcję kapelana polskich dziewcząt. Angażował się także w duszpasterstwo polonijne 
cie dumy i uznania, że mamy tutaj pionierów naszej sprawy, z energią i zapałem skupiających lud polski, czy to dorosłych, czy młodzież, czy dziewczęta samotne, by im nieść światło wiedzy, podnosić ich na duchu, i uczyć ich kochać Ojczyznę miłością tęsknoty tym najszczytniejszym przywiązaniem.

Uważam teraz za wskazane otwarcie Waszej Ekscelencji wypowiedzieć moją opinię, boć sprawa o którą chodzi, nie należy co prawda do moich kompetencji, lecz mimo to bardzo na sercu mi leży.

Pozostawiające bardzo dużo do życzenia położenie duszpasterstwa we Francji ma dwie przyczyny. Jedną zasadniczą, której się usunąć nie da, jest silny instynkt narodowy kleru francuskiego, który uważa że wychodźstwo polskie ma się jak najszybciej wynaradawiać i że dlatego nie należy się odnosić do księży polskich tak życzliwie i z taką pomocą, jakiej by wymagał bezwzględny interes Kościoła choćby już z tego względu, że wynaradawiający się robotnik polski równocześnie i zatraca $\mathrm{w}$ znacznej mierze poczucie katolickie (doświadczenia z Westfalii). Kler francuski po większej części znajduje się w skromnym położeniu materialnym i widzi w księdzu polskim konkurenta umniejszającego proboszczowi jego dochody. Wreszcie jest episkopat francuski nadzwyczaj niezależny w obrębie odnośnych diecezji, a zatem położenie księży polskich uwarunkowane jest w najwyższym stopniu także dobrą wolą pojedynczych Ks. Biskupów.

To są do pewnego stopnia ,imponderabilia” z którymi jako z faktami liczyć się trzeba, których całkowite usunięcie bodaj nigdy nie nastąpi.

Drugą przyczyną jest niedostateczna organizacja Polskiej Misji Katolickiej: jest to temat przykry, bo z ks. Rektorem Szymborem nie tylko miłe łączą nas stosunki osobiste, lecz mamy dla niego jako zacnego, beznagannego kapłana pełne uznanie - jest atoli moim obowiązkiem stwierdzić, że nie stoi on na wysokości zadania. W jego działalności nie widzę celowości i konsekwencji. Zamiast skierować wszystkie swoje wysiłki ku uzyskaniu wysokiego poziomu moralnego podporządkowanych mu księży; dobrej organizacji mogącej jak najlepiej wyzyskać siły będące do dyspozycji, solidarności między klerem, bezwzględnego choć opartego wyłącznie na idealnych przesłankach posłuszeństwa wobec Rektora - Ksiądz Szymbor interesuje się sprawami nie należącymi do zakresu jego działania np. kolonizacją polską w Algierze czy Tunisie (problem nadzwyczaj skomplikowany mogący wywołać niepotrzebne tarcia międzynarodowe) pisaniem artykułów do prasy krajowej, wywołujących nieraz démarches tutejszego Ministerstwa Spraw Zagranicznych przeciwko ks. Szymborowi (odnośną notatkę załączam), a poza tym pieniężnie źle się rządzi i ciągle ma długi, a efektu w stosunku do dochodów nie widać. Kilkakrotnie zaznaczali księża wobec mnie, że podział pracy na prowincji powinien być lepszy, że ich siły

w Lille, gdzie mieszkał, oraz okazjonalnie w koloniach polskich Harnes, Billy-Montigny, Roubaix i Tourcoing. Po powrocie do kraju w 1927 został profesorem w seminarium i liceum diecezjalnym. Po aresztowaniu przez Niemców 19 września 1939 został po kilku dniach zwolniony, kontynuował do 9 grudnia zajęcia w seminarium. Następnie do aresztowania 6 października 1941 pełnił posługę duszpasterską we wsi Białe k. Gostynina. Od 30 października był więźniem obozu koncentracyjnego w Dachau (nr obozowy 28403). Po wyzwoleniu podjął posługę duszpasterską wśród wychodźstwa polskiego we Francji. Do kraju powrócił 17 listopada 1947 i podjął obowiązki wicedyrektora Liceum im. Św. Stanisława Kostki. W 1954 został dyrektorem. Zmarł 11 grudnia 1960 w Warszawie. Pochowany został w Płocku. M. Grzybowski, Duchowieństwo diecezji płockiej, Wiek XX, T. 1, Cz. 2, Płock 2008, s. 232-234; W. Góralski, Skład osobowy Kapituły Katedralnej Płockiej w okresie rząów diecezja biskupa Tadeusza Pawła Zakrzewskiego (1946-1961), „Studia Płockie” 35 (2007) s. 249; Materiały, z. IV/II, Księża polscy, s. 105-106; M. Brudzisz, Pierwsze zebranie księży Polskiej Misji Katolickiej we Francji, „Studia Polonijne”, 33 (2012) s. 145. 
nie są całkowicie wyzyskane, a cierpią na tym liczne ośrodki mogące mieć i w teraźniejszych warunkach więcej pieczy duchowej.

Choć powyżej cytowałem nie moje zdanie, i ja się przychylam do tego przeświadczenia, że Rektorem Misji powinien być duchowny, praktycznie obyty z organizowaniem, doświadczony, mający wysoki prestiż osobisty, i bezwzględny takt. Takiego prestiżu Ks. Szymbor nie posiada i wątpię by go nabył, bo zdołano go podciąć (cfr. Ks. Helenowski) a to trudno odrobić. I taktu mu brak, przypominają mi się jego zajścia z niejakim Białym, którymi najniezgrabniej pokierował i które byłyby się prawdopodobnie zakończyły skandalem w prasie na wychodźstwie i w kraju, gdybym nie był sam zainterweniował.

Trzeba z tego sobie zdać sprawę, że stanowisko Rektora jest jednym z najtrudniejszych jakie sobie wystawić można, i dlatego łatwą jest krytyka. Mimo wszystko jednak mam to wrażenie, że Ks. Rektor Szymbor nie zdoła tak uzdrowić stosunków, jak one tego wymagają, ani zapewnić tak sprawnego funkcjonowania Misji, jakie leży w interesie Kościoła i Państwa.

Także stosunek Ks. Szymbora do czynników francuskich nie jest mi jasnym - z jednej strony - tj. ze strony wychodźstwa zarzuca mu się wobec kleru francuskiego zbyt wielką ustępliwość, z drugiej zaś - jak wyżej wspomniałem - właśnie w ostatnich czasach ponownie zwracało tutejsze Ministerstwo Spraw Zagranicznych uwagę na zdaniem tego Ministerstwa nietaktowne wystąpienia Ks. Szymbora w prasie krajowej.

Z dobrym kierownictwem Misji powinien iść w parze odpowiedni dobór duchownych dla Francji przeznaczonych i znaczne powiększenie ich zastępu.

Korzystając z formy prywatnego listu wypowiedziałem się wobec Waszej Ekscelencji całkiem otwarcie i szczerze, a cieszyłbym się gdyby moje wywody przydały się Waszej Ekscelencji i ułatwiły Jej obiektywne zorientowanie się w położeniu rzeczy.

Pragnąłbym przy tej okazji poinformować całkiem poufnie Waszą Ekscelencję, że z zagranicznych źródeł urzędowych dotarły do mnie aluzje, że Episkopat Niemiecki nosi się z zamiarem zrobienia ankiety w Polsce w sprawie niemieckiej mniejszości narodowej, którą pragnąłby zużyć w Rzymie. Zwracano moją uwagę na „Germania” z 13ego stycznia br. i na „Deutsche Arbeit” z grudnia.

Co jest w tym prawdy nie wiem, lecz jest objawem ciekawym, że poufnie kolportują takie wiadomości zagranicą.

Proszę Waszą Ekscelencję przyjąć wyrazy mojego najgłębszego szacunku i poważania - [dalej odręcznie] $i$ zechcieć odczytujac powyższe pismo, dyktowane na podstawie może zbyt ostro interpretowanych podkładek. Kierować się wyrozumiałościa dla ciężkich warunków działalności Księdza Rektora, któremu może w I. rzędzie brak instrukcji i kontroli budżetu.

W[aszej]. E[kscelencji]. oddany Alfred Chtapowski Ambasador Rzeczypospolitej Polskiej 
PASTORAL CARE OF POLES IN FRANCE BEFORE 1926 AS JUDGED BY AMBASSADOR ALFRED CHLAPOWSKI

\begin{abstract}
Summary
Polish emigration in France was almost exclusively represented by the Polish workers who were Roman Catholic most of the cases, and in vast majority attached to the Church - which was highlighted in a personal letter written by the Ambassador of Poland in Paris. Recognizing political influences and communities in which fellow countrymen worked, the Ambassador tried to remedy the status quo by the letter addressed to Cardinal A. Hlond. According to the letter, the work performed reasonably and sensibly by the Polish clergymen had a crucial impact upon the Polish emigration. Transmitting the related compiled dossier to the Primate, he judged the performance of the Polish pastoral care in France to the extent of opportunities and negligence in respect of the Church and Homeland before 1926.
\end{abstract}

Translated by Monika Zielińska-Choina 